\title{
DETERMINASI KEPUTUSAN REVALUTASI ASET TETAP (Studi Kasus Pada BUMN Listed di Bursa Efek Indonesia)
}

\author{
Leli Marlina \\ Sekolah Menengah Atas Negeri 1 Bireuen \\ Email: daffaummu730@gmail.com
}

\begin{abstract}
ABSTRAK
Penelitian ini merupakan penelitian kuantitatif yang mempunyai tujuan untuk mengetahui pengaruh fixed assets intensity, leverage, liquidity, cash flow from operation, dan firm size terhadap keputusan revaluasi aset tetap. Populasi yang digunakan dalam penelitian ini adalah perusahaan BUMN yang terdaftar di Bursa Efek Indonesia (BEI) tahun 2013-2017. Jumlah sampel yang didapatkan dengan menggunakan beberapa kriteria adalah sebesar 100 data. Penelitian ini menggunakan metode Analisis Regresi Logistik dengan bantuan program olah data E-Views (Statistical Product and Service Solution) versi 10. Hasil dari penelitian ini menunjukkan bahwa variabel fixed asset intensity tidak berpengaruh terhadap keputusan revaluasi aset tetap, variabel liquidity dan variabel cash flow from operation berpengaruh negatif signifikan terhadap keputusan revaluasi aset tetap. Sedangkan, variabel leverage dan firm size berpengaruh positif signifikan terhadap keputusan revaluasi aset tetap
\end{abstract}

Kata Kunci : Revaluasi Aset Tetap; Fixed Asset Intensity, Leverage, Liquidity, Cash Flow From Operation, Firm Size

\section{Pendahuluan}

Aset tetap merupakan kekayaan yang dimiliki oleh perusahaan dimana aset ini dibeli oleh perusahaan tidak untuk dijual, tetapi digunakan untuk dalam kegiatan operasional perusahaan. Aset tetap biasanya memiliki masa pemakaian jangka panjang atau dimanfaatkan lebih dari satu periode akuntansi. Aset tetap menurut PSAK 162012 adalah aset berwujud yang digunakan dalam operasi perusahaan dan tidak dimaksudkan untuk dijual dalam rangka kegiatan normal perusahaan, sehingga penggunaan aset tetap ini akan dalam jangka waktu lama. Aset tetap merupakan salah satu komponen penting dalam menjalankan kegiatan operasional perusahaan (Andison, 2015). Penggunaan aset tetap secara efisien akan menentukan kinerja suatu perusahaan (Latifa, 2016). Umumnya, aset tetap dinilai berdasarkan harga perolehan, lalu disusutkan nilainya selama masa manfaat aset tetap sehingga nilainya semakin lama semakin kecil. Penggunaan harga perolehan dalam penilaian aset menjadikan beberapa nilai aset tetap menjadi tidak relevan, karena tidak menunjukkan nilai terkini dari aset tetap yang dimiliki oleh perusahaan (Latifa, 2016).
Revaluasi aset tetap adalah penilaian ulang nilai aset tetap yang dilakukan perusahaan baik untuk tujuan akuntansi maupun tujuan perpajakan. Revaluasi aset tetap untuk tujuan akuntansi, dimaksudkan bahwa revaluasi aset tetap harus dilakukan berdasarkan nilai pasar atau nilai wajar aset tetap tersebut, sehingga nilai aset tetap yang disajikan dalam laporan keuangan menjadi relevan. Kerelevanan nilai aset ini akan bermuara pada kinerja perusahaan di masa datang.

Penilaian aset tetap dengan metode revaluasi memberikan penyajian kekayaan perusahaan yang wajar dan lebih relevan dalam pengambilan keputusan. Tetapi di Indonesia pilihan metode revaluasi masih kurang diminati meskipun kebijakan palaporan keuangan dan peraturan pemerintah memperkenankan perusahaan untuk memilih metode biaya atau metode revaluasi dalam menilai aset tetapnya. Hal tersebut disebabkan karena konsekuensi pajak yang harus perusahaan tanggung dengan persentase yang cukup besar atas surplus revaluasi.

Penelitian mengenai revaluasi aktiva tetap telah banyak dilakukan oleh beberapa peneliti sebelumnya baik di Indonesia 
maupun di luar negeri, namun terdapat hasil penelitian yang berbeda- beda sehingga perlu dilakukan pengujian lebih lanjut untuk mengetahui kesesuaian aspek-aspek yang diteliti apabila diterapkan pada kasus dan dimensi penelitian yang berbeda. Penelitian ini bertujuan untuk menguji secara empiris terkait pengaruh fixed asset intensity, leverage, liquidity, cash flow from operation dan firm size terhadap keputusan revaluasi aset tetap BUMN listed di Bursa Efek Indonesia.

\section{Kajian Teoritis}

\section{a. Teori Akuntansi Positif}

Positive accounting theory yang diperkenalkan oleh Watt dan Zimmerman (1990), menjelaskan mengapa perusahaan memilih kebijakan akuntansi sebagai bagian dari permasalahan yang mendalam dari meminimalkan biaya kontrak dan untuk mencapai efisiensi corporate governance. Teori akuntansi positif digunakan untuk menjelaskan motivasi melakukan revaluasi aset (Azouzi dan Jarboui, 2012). Dari bahasan di atas dapat dikatakan bahwa manajer akan memilih kebijakan akuntansi yang sesuai dengan tujuan mereka atau dengan kata lain manajer secara rasional akan memilih kebijakan akuntansi yang menurut mereka menguntungkan perusahaan.

\section{b. Aset Tetap}

Setiap perusahaan mempunyai harta (aset) untuk mendukung kegiatan usahanya. Pengertian aset tetap menurut PSAK 16 (2012) menyatakan bahwa ; "Aset tetap adalah aset tetap yang berwujud yang diperoleh dalam bentuk siap pakai atau dengan dibangun terlebih dahulu yang digunakan dalam operasi perusahaan dan mempunyai masa manfaat lebih dari satu tahun". Menurut PSAK No.16 (2012), perusahaan dapat memilih model biaya atau model revaluasi dalam pencatatan nilai aset tetapnya. Berdasarkan uraian diatas dapat disimpulkan bahwa didalam menetapkan kebijakan akuntansi terhadap aset tetap yang diakui sebagai aset, perusahaan dapat memilih dua model yang sesuai dengan intensi perusahaan. Dua model tersebut adalah:

1. Model Biaya . Model biaya adalah model historis yang selama ini kita kenal, dimana setelah diakui sebagai aset, aset tetap dicatat sebesar biaya perolehan dikurangi akumulasi penyusutan dan rugi penurunan nilai aset tetap.

2. Model revaluasi. Aset tetap yang nilai wajarnya dapat diukur dengan andal harus dicatat pada jumlah revaluasi yaitu nilai wajar pada tanggal revaluasi dikurangi akumulasi penyusutan dan akumulasi rugi penurunan nilai yang terjadi terjadi setelah tanggal revaluasi. Revaluasi dilakukan dengan teratur dan cukup umum agar dapat dipastikan bahwa jumlah yang tercatat tidak berbeda secara meterial dengan jumlah yang ditentukan dengan menggunakan nilai wajar secara material dengan jumlah yang ditentukan dengan menggunakan nilai wajar pada akhir periode pelaporan.

\section{c. Revaluasi Aset Tetap}

Revaluasi aset tetap adalah penilaian kembali aset tetap perusahaan. Revaluasi aset tetap dapat menjadi pilihan manajemen ketika adanya indikasi kenaikan nilai aset tetap di pasaran sementara nilai aset tetap pada laporan keuangan perusahaan masih mencantumkan nilai perolehan awal yang sudah tidak relevan dengan periode pelaporan akuntansi. Rudianto (2012), menyatakan revaluasi adalah model penilaian aset yang didasarkan pada harga pasar ketika laporan keuangan disajikan. Penggunaan metode ini akan memberikan gambaran yang lebih akurat tentang nilai aset yang dimiliki perusahaan pada suatu waktu tertentu. Revaluasi aset tetap umunya lebih diminati oleh perusahaan-perusahaan yang listed di bursa efek, hal ini terkait dengan tutuntan good corporate governance sebagai upaya perusahaan dalam meningkatkan kinerja dan memaksimalkan nilai perusahaan secara jangka panjang.

Selanjutnya yang menjadi dasar hukum revaluasi aset tetap di Indonesia adalah sebagai berikut:

1. Peraturan Menteri Keuangan Republik Indonesia Nomor 191/PMK.010/2015 tentang Penilaian Kembali Aset Perusahaan untuk Tujuan Perpajakan bagi Permohonan yang Diajukan pada Tahun 2015 dan Tahun 2016.

2. Peraturan Menteri Keuangan Republik Indonesia Nomor 233/PMK.03/2015 
tentang Perubahan Atas Peraturan Menteri Keuangan Nomor 191/PMK.03/2015 tentang Penilaian Kembali Aset Perusahaan untuk Tujuan Perpajakan bagi Permohonan yang Diajukan pada Tahun 2015 dan Tahun 2016

3. Undang-Undang Pajak Penghasilan (UU PPh) No. 36 Tahun 2008.

d. Faktor-Faktor yang Mempengaruhi Revaluasi Aset Tetap

Fixed Asset Intensity

Fixed asset intensity (intensitas asset tetap) merupakan proporsi aset perusahaan yang terdiri dari aset tetap (Tay, 2009). Peranan aset tetap dalam mendukung kegiatan operasional perusahaan cukup besar. Kompensasi modal yang berada pada pos aset tetap bernilai lumayan besar atau dapat dikatan bahwa aset tetap adalah aset perusahaan yang menyerap hampir sebagian besar sumber modal perusahaan (Ernawati, 2014). Fixed asset intensity diukur dengan rumus:

$$
F A I=\frac{\text { Total Aset Tetap }}{\text { Total Aset }}
$$

\section{Leverage}

Leverage menggambarkan proporsi utang terhadap aset ataupun ekuitas (Murhadi, 2015). Menurut Riyanto (2001), "rasio utang adalah gambaran kemampuan suatu perusahaan dalam melunasi semua hutang jangka pendek dan hutang jangka panjangnya". Rasio ini dihitung dengan rumus:

$$
L E V=\frac{\text { Total Hutang }}{\text { Total Ekuitas }} \times 100 \%
$$

\section{- Likuidity}

Menurut Andison (2015) rasio liquidity adalah rasio yang menjelaskan tingkat kemampuan perusahaan dalam membayar hutang lancarnya pada saat jatuh tempo. Perusahaan yang memiliki likuiditas rendah akan memilih melakukan revaluasi agar dapat menunjukkan nilai aset tetap perusahaan yang sebenarnya dapat diubah kedalam bentuk kas. Rasio likuiditas dihitung dengan rumus berikut

$$
L I Q=\frac{\text { Aktiva Lancar }- \text { Persediaan }}{\text { Kewajiban Lancar }}
$$

\section{- Cash Flow From Operation}

Syakur (2009), menyatakan bahwan arus kas operasi (cash flow from operation ) adalah aktivitas yang menunjukkan jumlah pemasukan dan pengeluaran dalam suatu periode tertentuyang berasal dari sumber kegiatan operasional perusahaan. Rumus untuk menghitung CFFO adalah sebagai berikut:

$$
\text { CFFO }=\frac{\text { Perubahan CFFO selama } 2 \text { Tahun }}{\text { Total Asset Tetap }}
$$

- Firm Size

Menurut Brigham \& Houston (2014) ukuran perusahaan adalah ukuran besar kecilnya sebuah perusahaan yang ditunjukan atau dinilai oleh jumlahl aset, jumlah penjualan, jumlah laba, beban pajak dan lain-lain. Firm size diukur dengan rumus:

Firm Size $=$ LnTotal Aset

\section{Metodelogi}

Metode analisis data yang digunakan dalam penelitian ini adalah uji statistik deskriptif dan uji hipotesis dengan menggunakan regresi logistik biner (binary logit). Lokasi penelitian ini dilakukan pada setiap perusahaan Badan Umum Milik Negara (BUMN) Indonesia.

Populasi yang diambil pada penelitian ini adalah perusahaan BUMN Listed di Bursa Efek Indonesia pada rentang tahun 2013 sampai dengan tahun 2017. Jumlah populasi tersebut yaitu 118 perusahaan (Website Kementrian BUMN RI, 2018). Data sekunder berupa data laporan keuangan tahunan perusahaan BUMN dari tahun 2013-2017 yang dipublikasikan melalui situs resmi seperti www.bumn.go.id. Data yang diambil berupa fixed asset intensity, leverage, liquidity, cash flow from operation dan firm size. Sampel penelitian ini dipilih berdasarkan kriteria sebagai berikut:

1. Perusahaan-perusahaan BUMN yang terdaftar di Kementrian BUMN dan tidak keluar (delisted) sepanjang tahun 2013-2017.

2. Tidak melakukan penggabungan (merger) selama periode 2013-2017. 
Adapun sampelnya adalah Bank Mandiri, 4 PT. BNI, 5 PT. BRI, 6 PT. BTN, 7 PT. Garuda Indonesia, 8 PT. Indofarma, 9 PT. Jasa Marga, 10 PT. Kimia Farma, 11 PT. Krakatau Steel, 12 PT. Pembangunan Perumahan, 13 PT. Perusahaan Gas Negara, 14 PT. Bukit Asam, 15 PT. Telekomunikasi Indonesia, 16 PT. Timah, 17 PT. Semen Indonesia, 18 PT. Semen Baturaja, 19 PT. Waskita Karya, 20 PT. Wijaya Karya

Metode analisis data yang digunakan dalam penelitian ini adalah uji statistik deskriptif dan uji hipotesis dengan menggunakan regresi logistik biner (binary logit). Dengan rumus:

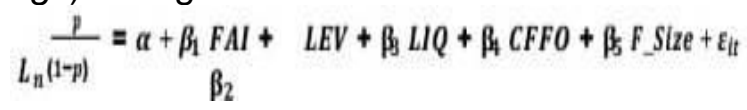

Keterangan :

$\mathrm{p}=$ Prediksi probabilitas $(\mathrm{RV}=1)$

$\alpha=$ Konstanta

$\beta$ 1. $\beta 2 . \beta 3 . \beta 4 . \beta 5=$ Koefisien regresi logit

$\mathrm{X}_{1}=\mathrm{FAl}$ (Fixed Asset Intensity)

$\mathrm{X}_{2}=L E V$ (Leverage)

$\mathrm{X}_{3}=L I Q$ (Liquidity)

$\mathrm{X}_{4}=$ CFFO (Cash Flow From Operation)

$\mathrm{X} 5=$ F Size (Firm Size)

eit $=$ Galat acak perusahaan ke-i pada waktu t

\section{Hasil dan Pembahasan}

\section{a. Statistik Desriptif}

Berikut ini uraian data hasil penelitian berdasarkan statistik deskriptif. Tabel 1. Statistik Deskriptif

\begin{tabular}{|c|c|c|c|c|c|c|}
\hline Variabel & Ilean & Median & Mavimum & Minimum! & Std. Der & Obs \\
\hline RV & 0,4200 & 0 & 1 & 0 & 0.4960 & 100 \\
\hline $\mathrm{FAl}$ & 0.2407 & 0.2061 & 0.9056 & 0.0063 & 0.2300 & 100 \\
\hline LEV & 26970 & 1.7653 & 113959 & 0.0891 & 25945 & 100 \\
\hline L. & 1.5338 & 1.2212 & 11.9519 & 0,3319 & 1.5741 & 100 \\
\hline CFFO & 0.1505 & 0.0222 & 13.6090 & 4.8964 & 1.8523 & 100 \\
\hline F SIIE & 31.2862 & 31.1352 & 34.6577 & 27.8529 & 1.7437 & 100 \\
\hline
\end{tabular}

Sumber: Hasil Analisis Datu, 2020

Tabel 1 menjelaskan bahwa variabel dependen berupa revaluasi aset memiliki nilai rata-rata 0,4200 , nilai maximum 1,00 , nilai minimum 0,00 dengan standar deviasi 0,4960 . Dari hasil diatas menjelaskan bahwa revaluasi aset tetap menjadi pilihan yang kurang baik karena standar deviasinya lebih besar dari nilai rata-ratanya, 0,4960> 0,4200 . hasil deskriptif variabel FAl untuk seluruh perusahaan. FAI memilikinilai rata- rata 0,2407 , nilai maximum 0,9056 , nilai minimum 0,0063 dengan standar deviasi 0,2300 . Nilai ini memenuhi persebaran data FAl yang merata dan berdistribusi dengan baik yaitu standar deviasi lebih kecil dibandingkan rata-ratanya atau 23,00<24.07 persen. Variabel $L E V$ memiliki nilai rata-rata 2,6970, nilai maksimum 11,3958, nilai minimum 0,0891dan standar deviasi sebesar 2,5946 . Nilai ini memenuhi persebaran data LEV yang merata dan berdistribusi dengan baik yaitu standar deviasi lebih kecil dibandingkan rata-ratanya atau $25,94<26,97$ persen. Variabel LIQ memiliki nilai rata-rata 1,5338 , nilai maksimum 11,9519 , nilai minimum 0,3319 dan standar deviasi sebesar 1,5741.Nilai standar deviasi LIQ lebih besar dibandingkan rata-ratanya yaitu 15,74 persen $>15,33$ persen. Hal ini mengindikasikan bahwa data LIQ tidak terdistribusi dengan baik dan tidak merata. Variabel CFFO memiliki nilai rata-rata 0,1505, nilai maksimum 13,6090, nilai minimum -4,8964, dan standar deviasi 1,85234. Nilai standar deviasi CFFO lebih besar dibandingkan rata-ratanya yaitu 18,52 persen > 15,05 persen. Hal ini mengindikasikan bahwa data CFFO tidak terdistribusi dengan baik dan tidak merata. Variabel F_Size memiliki nilai rata-rata 31,2862 , nilai maksimum 34,6577 , nilai minimum 27,8529 dan standar deviasi 1,7437. Nilai ini memenuhi persebaran data F SIZE yang merata dan berdistribusi dengan baik yaitu standar deviasi lebih kecil dibandingkan rata-ratanya atau 17,43 persen $<31,28$ persen

\section{b. Analisis Korelasi}

Hasil matriks korelasi antar variabel penelitian disajikan pada tabel 2. berikut:

Tabel 2. Korelasi Bivariat Antar ke-6 Variabel 


\begin{tabular}{|c|c|c|c|c|c|}
\hline Variabel & RV & FAl & LEV & $\triangle Q$ & CFFO \\
\hline \multirow[t]{3}{*}{ RV } & 1.0000 & & & & \\
\hline & $\ldots .$. & & & & \\
\hline & $\cdots$ & & & & \\
\hline \multirow[t]{2}{*}{ FAl } & $-0,0365$ & 1 & & & \\
\hline & -0.3616 & - & & & \\
\hline \multirow[t]{2}{*}{ LFV } & 0.1547 & -06037 & 1 & & \\
\hline & $(1.0505)^{*}$ & $(-5.4972)^{4 *}$ & - & & \\
\hline \multirow[t]{2}{*}{ LIQ } & -0.1445 & -0.0415 & -0.0898 & 1 & \\
\hline & $(-1.1460)^{*}$ & -0.4119 & -0.6929 & $\cdots$ & \\
\hline \multirow[t]{2}{*}{ CFFO } & -0.1604 & -0.0565 & 0.0709 & -0.0128 & 1 \\
\hline & $(-1.1096)^{*}$ & -0.5604 & 0.7039 & -0.1275 & - \\
\hline \multirow[t]{2}{*}{ F_SIZE } & 0.3420 & -0.2401 & 0.5911 & -0.1950 & 0.1434 \\
\hline & $(3,6030)^{* * t}$ & $(-24489)^{\prime \prime}$ & $(5.2549)^{* *}$ & $(-1.9689)^{* *}$ & 1.4352 \\
\hline
\end{tabular}

Sumber : Hasil Anulisis Data, 2020

Tabel 2 menunjukkan korelasi antar variabel penelitian secara keseluruhan. Variabel FAI memiliki korelasi negatif dengan RV dengan koefisien -0,3616 dan tidak signifikan dengan nilai $-p=0,71>0.01$. Variabel LEV memiliki hubungan positif dan signifikan dengan $\mathrm{RV}$ pada level $5 \%$,dengan nilai $r=1,0505$ pada probability $0,02<0,05$. Variabel LIQ memiliki hubungan negatif dan signifikan dengan $\mathrm{RV}$ pada level $5 \%$, dengan nilai $r=-1,14$ pada probability $0,01<0,05$. Variabel CFFO memiliki hubungan negatif dengan RV pada level $5 \%$, dengan nilai $r=-$ 1,10 pada probability $0,01<0,05$. Sedangkan variabel $F$ Size memiliki hubungan positif dengan $\mathrm{R} \overline{\mathrm{V}}$ pada taraf signifikan sebesar $1 \%$, dengan nilai $r=3,60$ pada probability $0,0005<0,001$

\section{c. Uji Likelihood} ini:

Hasil uji likelihood pad tabel 3 di bawah

\section{Tabel 3. Uji Likelihood Ratio}

\begin{tabular}{lrlr}
\hline McFadden R-squared & 0.1451 & Mean dependent var & 0.4200 \\
S.D. dependent var & 0.4960 & S.E. of regression & 0.4624 \\
Akaike info criterion & 1.2831 & Sum squared resid & 20.1070 \\
Schwarz criterion & 1.4394 & Log likelihood & .58 .1568 \\
Hannan-Quinn criter. & 1.3463 & Deviance & 116.3136 \\
Restr. deviance & 136.0584 & Restr. log likelihood & -68.02920 \\
LR statistic & 19.7448 & Avg. log likelihood & -0.5815 \\
Prob(LR statistic) & 0.0013 & & \\
\hline Obs with Dep - 0 & 58 & Total obs & 100 \\
Obs with Dep=1 & 42 & & \\
\hline
\end{tabular}

Sumber: Output E-liews

Berdasarkan hasil estimasi, diperoleh nilai LR statistik atau chi-square hitung adalah 19,7448, sedangkan nilai chi-square tabel df $5, \alpha=0,05$ diperoleh sebesar 11.0705. Nilai LR statistik atau chi- square hitung $(19,7448)>$ nilai chi-square tabel (11.0705). Selain itu, dapat melihat Uji LR dengan membandingkan Probability (LR statistik) pada $\alpha$, nilai Probability (LR statistik) $0.0013<0.05$, maka keputusannya adalah menerima $\mathrm{H}_{1}$ yang berarti semua variabel independen secara bersama-sama mempengaruhi variabel dependen.

\section{d. Uji Determinasi $\left(\mathbf{R M c F}^{2}\right)$}

Hasil uji determinasi pada tabel 4 di bawah ini:

Tabel 4. Uji Koefisien Determinasi $\left(\mathrm{RMcF}^{2}\right)$

\begin{tabular}{lrlr}
\hline McFadden R-squared & 0.1451 & Mean dependent var & 0.4200 \\
S.D. dependent var & 0.4960 & S.E. of regression & 0.4624 \\
Akaike info criterion & 1.2831 & Sum squared resid & 20.1070 \\
Schwarz criterion & 1.4394 & Log likelihood & -58.1568 \\
Hannan-Quinn criter. & 1.3463 & Deviance & 116.3136 \\
Restr, deviance & 136.0584 & Restr. log likelihood & -68.02920 \\
LR statistic & 19.7448 & Avg. log likelihood & -0.5815 \\
Prob(LR statistic) & 0.0013 & & \\
\hline Obs with Dep=0 & 58 & Total obs & 100 \\
Obs with Dep=1 & 42 & & \\
\hline
\end{tabular}

Sumber: Ouput E-Views

Hasil nilai estimasi McFadden R-Squared $\left(\mathbf{R} \mathbf{M c F} \mathbf{F}^{2}\right)$ sebesar 0,1451 . Hal ini berarti bahwa variabel bebas fixed asset intensity (FAI), leverage (LEV), liquidity (LIQ), cash flow from operation (CFFO) dan firm size ( $F \_$Size) dalam model mampu menerangkan perubahan probabilitas revaluasi aset tetap sebesar $14,51 \%$ dan selebihnya $85,49 \%$ perubahnnya dipengaruhi oleh variabel lain diluar model penelitian

\section{e. Hasil Estimasi Regresi Logistik Biner}

Hasil estimasi model logit yang ditunjukkan pada Tabel 5 berikut menjawab tujuan penelitian dan uji hipotesis (Uji Z) disebut juga sebagai uji partial

Tabel 5. Model Regresi Logistik Biner 


\begin{tabular}{crrr} 
Variabel & Coefficient & Std. Error & 7-Statistic \\
\hline C & -17.4373 & 1.3976 & -3.3124 \\
FAI & -0.0410 & 0.0530 & -0.0346 \\
LEV & 1.0697 & 1.2119 & $0.5235^{\prime *}$ \\
L.IQ & -1.3169 & 0.0383 & $-1.1377^{\prime *}$ \\
CFFO & -1.3471 & 0.0972 & $-1.8651^{\prime *}$ \\
F SIZE & 1.5669 & 0.2464 & $0.2619^{\prime *}$ \\
\hline
\end{tabular}

Sumber: Output E-Views

Keterangan : Tingkat signifikansi ditunjukkan dalam bentuk ${ }^{* * *},{ }^{* *},{ }^{*}$ pada signifikan level $1 \%$, $5 \%, 10 \%$.

Berdasarkan hasil output pada tabel 5, maka diperoleh persamaan model logit sebagai berikut:

$$
\begin{aligned}
& L \quad P=\alpha+\beta F A I+\beta \quad L E V+\beta L I Q+\beta \quad C F F O+\beta F \_ \text {Size }+\varepsilon \\
& n \overline{(1-p)} \quad 1 \quad 2 \quad 3 \quad 4 \quad 5 \quad \text { it }
\end{aligned}
$$$$
\text { atau }
$$

Revaluasi $=-17,4373+0,0410$ FII $+1,0697$ LEV $-1,3169$ LIQ $-1,3471$ CFFO + 1,5669 F Size

Berdasarkan persamaan regresi di atas dapat dijelaskan nilai koefisien regresi untuk konstanta sebesar $-17,4373$. Hal ini mengindikasikan bahwa jika variabel independen sama dengan 0 , maka kemungkinan perusahaan melakukan revaluasi aset tetap menurun sebesar $17,43 \%$

\section{f. Bahasan}

Pengaruh Fixed Asset Intensity (FAl) Terhadap Revaluasi Aset Tetap

Berdasarkan hasil output dapat dilihat bahwa nilai probabilitas variabel independen fixed asset intensity sebesar $0,9724>0,1$, sehingga dapat diambil keputusan untuk menolah $\mathrm{H} 1$. Hasil ini menjelaskan bahwa variabel fixed asset intensity tidak berpengaruh secara signifikan terhadap keputusan revaluasi aset tetap. Fixed asset intensity merupakan faktor yang mempengaruhi asimetri informasi karena manajamen lebih banyak mengetahui mengenai intensitas aset tetap dibandingkan dengan pemilik perusahaan hal ini berkaitan dengan keputusan dalam melakukan revaluasi aset tetap. Seperti yang diketahui bahwa untuk melakukan revaluasi aset tetap membutuhkan biaya yang besar karena dilakukan oleh pihak lain diluar perusahaan dan hanya akan menambah beban pajak atas aset tetap setelah revaluasi sehingga menjadi pertimbangan manajamen untuk tidak melakukan revaluasi aset tetap. Hasil penelitian ini sesuai dengan hasil penelitian sebelumnya yang dilakukan oleh Khairati (2015) yang tidak menemukan pengaruh fixed asset intensity terhadap revaluasi aset tetap. Hasil ini juga sejalan dengan penelitian Lin dan Peasnel (2000a), Seng dan Su (2010), Yulistia dkk. (2012) dan Khairati (2015), menyatakan bahwa tidak adanya hubungan fixed asset intensity terhadap keputusan perusahaan untuk melakukan revaluasi asset tetap. Hasil penelitian ini berbeda dengan penelitian yang dilakukan Cut Annisa Latifa dan Musfiari Haridhi (2014) yang berhasil menemukan hubungan positif antara fixed asset intensity dengan keputusan perusahaan melakukan revaluasi aset tetap.

\section{Pengaruh Leverage (LEV) Terhadap Revaluasi Aset Tetap}

Berdasarkan hasil output dapat dilihat bahwa nilai probabilitas variabel leverage sebesar 0,0006 . Bila dibandingkan dengan $\alpha=0,001$ maka nilai probabilitas $(0,0006)<$ nilai a $(0,001)$, sehingga dapat diambil keputusan untuk menerima $\mathrm{H}_{2}$. Hasil ini menjelaskan bahwa secara parsial variabel leverage (LEV) berpengaruh positif signifikan terhadap revaluasi aset tetap. Pengaruh positif leverage terhadap revaluasi aset tetap menunjukkan bahwa terjadi hubungan positif antara leverage dengan revaluasi aset tetap dimana semakin tinggi leverage maka semakin besar kemungkinan perusahaan untuk melakukan dan menggunakan revaluasi sebagai metode pengukuran setelah pengakuan awal aset tetapnya. Hasil ini sejalan dengan penelitian yang dilakukan oleh Lin dan Peasnell (2000), MissonierPiera (2007), Seng dan Su (2010) dan Manihuruk (2015) yang juga menemukan adanya pengaruh positif leverage terhadap revaluasi aset tetap. Namun hasil penelitian ini bertentangan dengan penelitian yang dilakukan oleh Sudrajat, Ahmar, Mulyadi (2017) yang menyatakan bahwa leverage berpengaruh negatif terhadap revaluasi aset tetap.

Pengaruh Liquidity (LIQ) Terhadap 


\section{Revaluasi Aset Tetap}

Berdasarkan hasil output dapat dilihat bahwan nilai probabilitas variabel liquidity sebesar 0,0052. Bila dibandingkan dengan $\alpha=1 \%$, maka nilai probabilitas $(0,0052)<$ nilai a $(0,001)$, sehingga dapat diambil keputusan untuk menerima $\mathrm{H} 3$. Hasil ini menjelaskan bahwa variabel liquidity berpengaruh negatif signifikan terhadap perusahaan untuk melakukan revaluasi aset tetap. Koefisien negatif liquidity menunjukkan bahwa semakin tinggi rasio liquidity maka keputusan manajemen untuk melakukan revaluasi aset tetap akan menurun dan sebaliknya. Rasio liquidity menggambarkan kemampuan perusahaan dalam melunasi kewajiban lancarnya.Tergantung pada tingkat likuiditas, perusahaan mungkin memutuskan untuk melakukan revaluasi atau tidak terhadap aset tetap. Hal ini karena kebijakan revaluasi dapat menawarkan bantuan dengan memberikan informasi lebih terhadap jumlah uang yang berasal dari penjualan aset, dan dengan demikian meningkatkan kapasitas pinjaman dari perusahaan. Penelitian Tay (2009) membuktikan bahwa rasio likuiditas berpengaruh negatif terhadap kebijakan revaluasi aset. Hal yang sama juga dibuktikan pada penelitian Andison (2015) dan penelitian Manihuruk dan Farahmita (2015) yang menyatakan hubungan negatif likuiditas terhadap revaluasi aset tetap.

\section{Pengaruh Cash Flow From Operation Terhadap Revaluasi Aset Tetap}

Berdasarkan hasil output dapat dilihat bahwan nilai probabilitas variabel cash flow from operation sebesar 0,0022. Bila dibandingkan dengan $\alpha=1 \%$, maka nilai probabilitas $(0,0022)<$ nilai $\alpha(0,001)$, sehingga dapat diambil keputusan untuk menerima $\mathrm{H} 4$. Hasil ini menjelaskan bahwa secara parsial variabel CFFO berpengaruh negatif signifikan terhadap perusahaan untuk melakukan revaluasi aset tetap. Koefisien negatif varibel CFFO bermakna bahwa semakin tinggi arus kas operasi suatu perusahaan maka akan menyebabkan perusahaan tidak memilih revaluasi aset tetap sebagai metode pencatatan aset tetapnya, demikian sebaliknya. Penelitian ini sejalan dengan penelitian Seng dan Su (2010) yang memiliki hasil negatif terhadap variabel arus kas operasi pada kebijakan revaluasi aset tetap. Sama halnya dengan penelitian yang dilakukan oleh Yulistia, et.al (2015) yang tidak berhasil membuktikan pengaruh dari variabel arus kas operasi terhadap perusahaan untuk melakukan revaluasi aset tetap.

\section{Pengaruh Firm Size Terhadap Revaluasi Aset Tetap}

Berdasarkan hasil output dapat dilihat bahwa nilai probabilitas variabel firm size sebesar 0,0001 . Bila dibandingkan dengan $\alpha=1 \%$, maka nilai probabilitas $(0,0001)<$ nilai $\alpha(0,001)$, sehingga dapat diambil keputusan untuk menerima $\mathrm{H} 5$. Hasil ini menjelaskan bahwa cecara parsial variabel Firm Size berpengaruh positif signifikan terhadap revaluasi aset tetap. Pengaruh positif variabel Firm Size bermakna bahwa semakin besar ukuran suatu perusahaan maka semakin dipilihnya metode revaluasi aset tetap sebagai metode pencatatan aset tetap perusahaan, demikian sebaliknya. Firm size adalah salah satu indikator perhatian politis dan perusahaan berusaha menghindari atau meminimalkan perhatian tersebut. Barac dan Sodan (2011), menyatakan bahwa revaluasi dapat meningkatkan nilai aset dan beban depresiasi masa depan karena beban depresiasi dihitung berdasarkan nilai aset yang telah berubah sehingga mengurangi perhatian politis. Seng dan Su (2010), mengemukakan bahwa " seringkali nilai aset tetap meningkat secara signifikan akibat revaluasi. Sehingga ukuran perusahaan berpengaruh terhadap keputusan perusahaan dalam memilih metode revaluasi untuk pencatatan aset tetap". Hasil ini sejalan dengan penelitian Khairati (2015) dan Firmansyah dan Syerlita, (2010

\section{Penutup Implikasi Secara Teoritis}

Penelitian ini telah menghasilkan beberapa implikasi secara teoritis yaitu: Fixed asset tidak memiliki arah pengaruh yang signifikan terhadap keputusan revaluasi aset tetap. Hal ini bertentangan dengan hipotesis alternatif namun dapat mendukung beberapa hasil penelitian 
terdahulu. Tidak adanya pengaruh fixed asset intensity terhadap keputusan revaluasi aset tetap dikarenakan hal terkait dampak revaluasi aset tetap, yaitu semakin besar jumlah aset tetap yang dimiliki perusahaan maka biaya jasa penilai (valuer fee), dan biaya pajak atas revaluasi juga semakin besar. Hal ini mengakibatkan keuntungan revaluasi aset tetap tidak sebanding dengan manfaat yang dihasilkan, maka manajer lebih memilih untuk tidak melakukan revaluasi aset tetap.

\section{Implikasi Secara Teoritis}

Hasil penelitian ini menunjukkan bahwa intensitas aset tetap tidak memiliki pengaruh signifikan terhadap keputusan revaluasi aset tetap. Dengan kata lain, tinggi rendahnya intensitas aset tetap perusahaan tidak berdampak pada keputusan manajer untuk memilih model revaluasi. Dengan demikian, peneliti dapat memberikan implikasi praktis bagi pemerintah, bahwa pemerintah perlu melakukan revisi kebijakan di bidang perpajakan dengan mempertimbangkan dua hal penting yaitu penghapusan pajak $10 \%$ atas revaluasi dan memberikan izizn kepada BUMN untuk merevaluasi aset mereka setiap tahun dengan mengikuti PSAK No.16. Masalah perpajakan perlu menjadi perhatian pemerintah dan pengusaha termasuk BUMN sebagai wajib pajak mengingat setoran pajak masih menjadi tulang punggung anggaran pemerintah.

\section{Kesimpulan}

Dari hasil pengujian hipotesis diperoleh kesimpulan dari penelitian, bahwa: Fixed Asset Intensity tidak memilki pengaruh signifikan terhadap keputusan revaluasi aset tetap pada perusahaan BUMN listed di Bursa Efek Indonesia tahun 2013-2017. Leverage berpengaruh positif signifikan terhadap signifikan terhadap keputusan revaluasi aset tetap pada perusahaan BUMN yang listed di Bursa Efek Indonesia tahun 2013-2017. Liquidity berpengaruh negatif signifikan terhadap keputusan revaluasi aset tetap pada perusahaan BUMN listed di Bursa Efek Indonesia tahun 2013-2017. Cash Flow From Opreation berpengaruh negatif signifikan terhadap keputusan revaluasi aset tetap pada perusahaan BUMN listed di Bursa Efek Indonesia tahun 2013-2017. Firm Size berpengaruh positif signifikan terhadap keputusan revaluasi aset tetap pada perusahaan BUMN yang listed di Bursa Efek Indonesia tahun 2013-2017.

$$
\text { Untuk menambah referensi }
$$

penelitian selanjutnya, ada beberapa saran yang dikemukakan: Ketika suatu perusahaan ingin meningkatkan intensitas aset tetapnya maka harus adanya kerja sama antara agent dan principal sehingga tidak menimbulkan asimetri informasi agar dapat mencapai tujuan perusahaan dengan baik. Begitupula ketika perusahaan memilih melakukan atau tidak melakukan revaluasi aset tetap. Bagi pihak manajemen agar mempertimbangkan faktor-faktor yang dapat mempengaruhi kebijakan revaluasi aset tetap, sehingga dapat menampilkan nilai laporan keuangan secara wajar untuk mengambil keputusan yang tepat. Mengukur aset tetap menggunakan nilai wajar adalah topik menarik yang membutuhkan penyelidikan lebih lanjut. Oleh sebab itu, disarankan juga untuk penelitian selanjutnya menggunakan variasi variabel lain yang mungkin berpengaruh terhadap kebijakan revaluasi aset tetap untuk melihat pengaruhnya seperti nilai pasar, return on equity, growth option, bonus issue, tax effect, dan umur IPO.

Penelitian ini hanya meneliti data laporan keuangan perusahaan BUMN yang terdaftar di Bursa Efek Indonesia, sehingga hasil yang diperoleh terbatas hanya untuk satu sektor perusahaan BUMN saja. Penelitian ini hanya menguji pengaruh variabel :fixed asset intensity (FAI), leverage (LEV), liquidity (LIQ), cash flow from operation (CFFO) dan firm size ( $F \_$Size). Ada beberapa variabel lain yang mungkin berpengaruh terhadap kebijakan revaluasi aset tetap tidak diuji dalam penelitian ini

\section{Daftar Pustaka}

Andison. (2015). "Fixed Asset Revaluation: Market Reactions", Jurnal yang disajikan dalam Prosiding Simposium Nasional Akuntansi XVIII, Medan.

Azouzi, Mohamed Ali dan Anis Jarboul. (2012). The Evidence of 
Managementmotivation to revalue property plant and Equipment in Tunisia. African Journal of Hospitality, Tourism and Leisure. Vol. 2(1).

Brigham, Eugene $\mathrm{F}$ and Joel F. Houston. (2014). Fundamentals of Financial. Management. 12th Edition. Mason: South-Westtern Cengage Learning.

Ernawati. (2014). Analisis Penerapan Standar Akuntansi Keuangan (PSAK NO 16) atas Aset Tetap pada PT. Pelayaran Liba Marindo Tanjungpinang. Skripsi. Universitas Maritim Raja Ali Haji

Ikatan Akuntan Indonesia. (2015). Exposure Draft Aset Tetap PSAK 16. Jakarta.

Latifa, Cut A., dan Haridhi, Musfiari. (2016). "Pengaruh Negosiasi Debt Contract, Political Cost, Fixed Asset Intensity, dan Market To Book Ratio Terhadap Perusahaan Melakukan Revaluasi Aset Tetap". Jurnal IImiah Mahasiswa Ekonomi Akuntansi, Vol. 1.

Manihuruk, Tunggul N., dan Farahmita, Aria. (2015). "Analisis Faktor-Faktor yang Mempengaruhi Pemilihan Metode Revaluasi Aset Tetap pada Perusahaan yang Terdaftar di Bursa Saham Beberapa Negara ASEAN". Jurnal yangdisajikan dalam Prosiding Simposium Nasional Akuntansi XVII. Medan.

Murhadi. (2015). Hukum Perusahaan: Bentuk-Bentuk Badan Usaha di Indonesia, Ghalia Indonesia.Bogor.

Rudianto. (2012). Pengantar Akuntansi : Konsep dan Penyusunan Laporan Keuangan. Erlangga.Jakarta

Seng, Dyna dan Jiahua Su. (2010). Managerial Incentives Behind Fixed Asset Revaluation: Evidence from New Zealand Firms, International Journal of Business Research, Department of Accountancy and Business Law, Working paper series, No 3.

Syakur, Ahmad Syafi'i (2009). Intermediate Accounting. AV Publisher. Jakarta.

Tay, Ink. (2009). "Fixed Asset Revaluation: Management Incentives and Market Reactions", Thesis, Lincoln University. 